\title{
NON-DESTRUCTIVE EVALUATION OF IN-PLACE REHABILITATED CONCRETE PAVEMENTS
}

\author{
Kasthurirangan Gopalakrishnan ${ }^{1}$, Sunghwan Kim ${ }^{2}$, Halil Ceylan ${ }^{3}$ \\ 1, 2,3Town Engineering Building, Iowa State University, Ames, IA 50011, USA \\ E-mails: ${ }^{1}$ rangan@iastate.edu(corresponding author); ${ }^{2}$ sunghwan@iastate.edu; ${ }^{3}$ hceylan@iastate.edu
}

Received 30 Mar. 2009; accepted 14 Jun. 2010

\begin{abstract}
Several in-place rehabilitation techniques have been used before placing an Asphalt Concrete (AC) overlay on Portland Cement Concrete (PCC) pavements in attempts to minimize reflection cracking. Among these techniques, "rubblization" of PCC has been recognized to be the most utilized procedure for the mitigation of reflection cracking in US. This paper presents the practices on the use of rubblization in US and discusses the performance of this technique based on field evaluation. The specifications for the rubblization procedure used by state Department of Transportation (DOT) in US were reviewed. To evaluate the performance of rubblization technique, the structural and the surface conditions of AC overlaid pavements with rubblized PCC layer are compared to those with virgin PCC layer. A series of field experiment tests were carried out on six representative AC overlaid pavements with both rubblized PCC and virgin PCC in Iowa during 2007. The field experiment tests include the Nondestructive (NDT) and destructive tests, and the distress survey. Deflection Basin Parameters (DBPs) were derived from NDT test results to characterize the structural condition of pavements. The results indicate that the rubblized PCC layer has strength comparable to that of virgin PCC layer and has better performance under that structural condition.
\end{abstract}

Keywords: concrete, asphalt, rehabilitation, pavement, nondestructive test, rubblization.

\section{Introduction}

Asphalt resurfacing on distressed Portland Cement Concrete (PCC) pavements is one of rehabilitation strategies that many agencies in the world have been used (Rolt et al. 1986, 1996; Ellis et al. 2002). However; reflection cracking is a main concern when applying a new asphalt surface to joints and crack in the underlying concrete. The movement of the PCC pavement (caused by traffic loading or thermally induced expansions and/or contractions or a combination of both) causes excessively high strains to develop at the bottom of the Asphalt Concrete (AC) overlay, above the joints and cracks, which leads to upward crack propagation, resulting in reflection (or reflective) cracking (Freeman 2002).

Several surface preparation techniques have been used before placing an AC overlay in attempts to minimize reflection cracking. Some of the most common techniques are fractured slab techniques including rubblization, crack-and-seat, break-and-seat, and saw and seal. The results from many comprehensive investigations in US conducted all indicate that rubblization among fractured slab techniques is the most utilized procedure for the mitigation of reflection cracking (PCS/Law 1991; NAPA 1994; Ksaibati et al. 1998).

Rubblization is an in-place rehabilitation technique that involves breaking the concrete pavement into pieces. The sizes of the broken pieces usually range from sand size to $75 \mathrm{~mm}$ ( 3 in) at the surface and 305 to $381 \mathrm{~mm}$
(12 to 15 in) on the bottom part of the rubblized layer (Von Quintus et al. 2007)

Considerable research in US and east Asia (PCS/Law 1991; NAPA 1994; Thompson et al. 1997; Ksaibati et al. 1998; Heckel 2002; Baladi et al. 2002; Timm and Warren 2004; Gulen et al. 2004; Scullion 2006; Wienrank and Lippert 2006; Von Quintus et al. 2007; Chen et al. 2008; Gucunski et al. 2009) has been conducted on rubblization in the recent past but this technique were not much studied in European countries as considering several research efforts for other fracture technique such as cracking and seat (Ellis et al. 2002). The results of research in US indicated that the performance of this technique varied from place to place and from project to project. These indicate that it is a need to gain more information on the performance of this technique significantly increasing the use as a viable rehabilitation strategy.

The primary objectives of this study were to present the practices on the use of rubblization in US and evaluate this technique with comparison of the structure and the surface condition of AC overlay pavements with rubblized PCC layer and those with PCC layer without rubblization. The specifications for the rubblization procedure of state Department of Transportation (DOT) in US were reviewed and presented. The six representative AC overlay pavement sections in Iowa were primary selected considering state wide location and pavement age. The series of field experiment tests were carried out at the 
selected test sections in 2007. The field experiment tests included the Nondestructive (NDT) and destructive tests, and the distress survey for the characterization of the structure condition and the surface condition, respectively. The procedures and the results of data analysis, especially analysis of Deflection Basin Parameters (DBPs) derived from Nondestructive test results, are discussed in this paper.

\section{Rubblization Technique}

The Asphalt Institute in the US has established a sevenpart process for rubblized pavements that is outlined below (Fitts 2001):

a) Remove any existing overlay;

b) Install an edge drainage system, preferably two weeks before fracturing the concrete;

c) Sawcut the full thickness of the PCC pavement, along the longitudinal joint, if the adjacent pavement is to remain intact;

d) Rubblize the PCC pavement;

e) Cut and remove exposed reinforcement;

f) Roll fractured PCC;

g) Place AC.

In general, two types of equipment are used in the rubblization process: Resonant Pavement Breaker (RPB) and Multiple-Head Breaker (MHB). The rubblization procedure plays an important role in long-term performance of the pavement. The RPB shown in Fig. 1a uses vibrating hammers to demolish the existing pavement. This system breaks the concrete slab and destroys the bond between the concrete and the steel. It works on the principle that the frequency of a vibratory force can be varied until the resonant frequency of the body being vibrated can be determined. More details of the equipment are available at the reference (Resonant Machines Inc. 2007).

The other common rubblizing equipment is the MHB as shown in Fig. 1b. The equipment is of the selfcontained and self-propelled type, which is capable of rubblizing the pavement over a maximum width of $4 \mathrm{~m}$ (13 ft.) per pass. The hammers used by this breaker are mounted laterally in pairs, with half of the hammers in the forward row and the remainder diagonally offset in the rear row. More details of this equipment are available at reference (Antigo Construction, Inc. 2007).

The Illinois DOT in the US specifies that the construction process begins with the installation of drainage elements, as required, and getting the surface prepared. The first consideration in Illinois DOT guidelines for rubblizing concrete pavements (Heckel 2002) is whether the rubblized pavement would protect the subgrade. If conditions exist that would result in extensive removal and replacement of the existing pavement, or if the subgrade is weak and would result in severe construction problems, Illinois DOT guidelines recommend the consideration of other rehabilitation options. Wisconsin DOT (2007) in the US also requires an investigation of subgrade strength, since construction practices consist of paving concrete pavements directly on top of subgrade, and

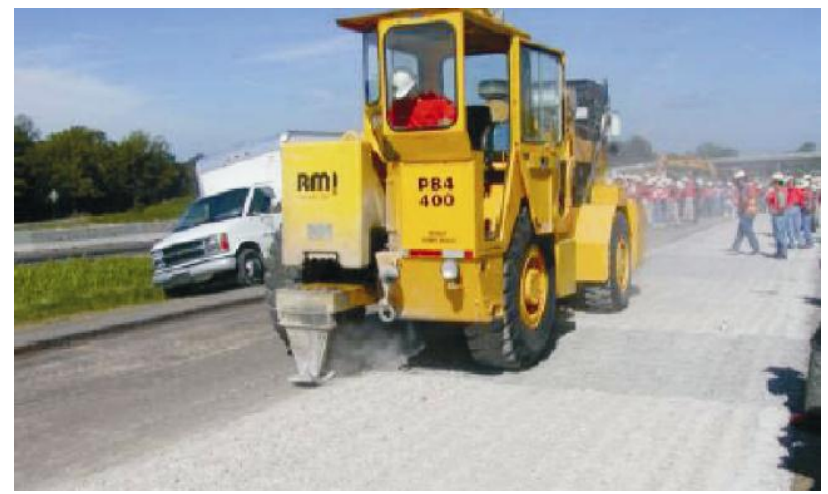

a)

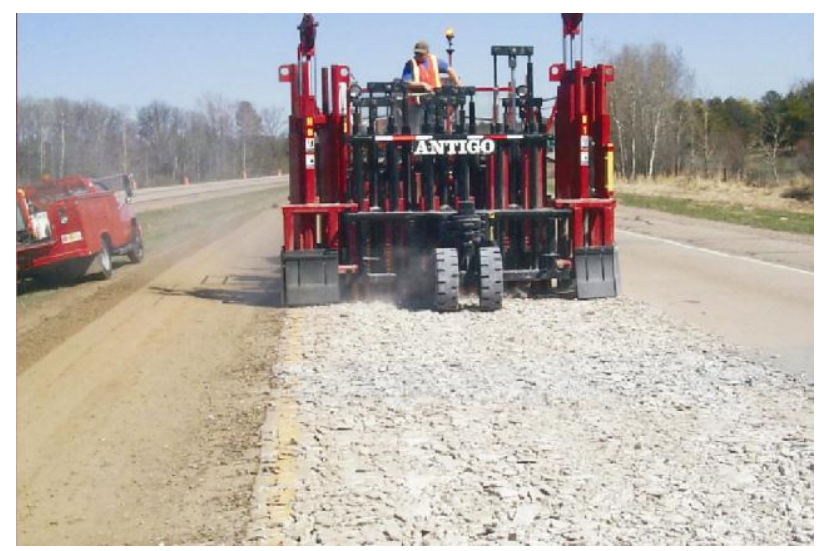

b)

Fig. 1. Equipment in the rubblization: a) Resonant Pavement Breaker (Resonant Machines, Inc. 2007); b) Multi-Head Breaker (Antigo Construction, Inc. 2007)

"weak" subgrades make rubblization susceptible to subgrade yielding problems.

Several DOTs in the US, including Arkansas (Arkansas DOT 2003), Michigan (Michigan DOT 2003), Ohio (Ohio DOT 2005), Illinois (Heckel 2002), and Alabama (Alabama DOT 2006) require the use of test strips and closely monitor them to calibrate the rubblization equipment to the existing site conditions. The 0.9 by $0.9 \mathrm{~m}$ ( 3 by $3 \mathrm{ft}$.) pit to physically observe the performance of the equipment confirms or denies the required particle sizes that are obtained at the bottom of the PCC pavement layer. The Illinois (Heckel 2002), Indiana (Indiana DOT 2006), and Ohio (Ohio DOT 2005) DOTs require that the $\mathrm{AC}$ overlay is placed on the rubblized concrete within 48 hours after the rubblization process. In the event of rain, the contractor is to delay overlay placement to provide sufficient time for the moisture to drain out or dry. The rubblization process is to be discontinued in the event of rain until the paving operation starts. Additionally, no traffic is allowed to drive on the pavement until the first lift of the overlay is placed.

\section{Experimental Data Collection}

A field experiment was carried out during summer in 2007 to evaluate the structure and surface condition of AC overlay pavements with rubblized PCC layer and 
Table 1. List of pavement sites for data collection

\begin{tabular}{|c|c|c|c|c|c|c|c|c|}
\hline \multirow{2}{*}{$\begin{array}{l}\text { Test Sec- } \\
\text { tion No. }\end{array}$} & \multicolumn{2}{|c|}{ Location } & \multicolumn{3}{|c|}{ Layer Thickness (mm) } & \multirow{2}{*}{$\begin{array}{c}\text { Rub- } \\
\text { blization }\end{array}$} & \multirow{2}{*}{$\begin{array}{l}\text { Average Daily Truck } \\
\text { Traffic (AADT) }\end{array}$} & \multirow{2}{*}{$\begin{array}{l}\text { Construction } \\
\text { Year }\end{array}$} \\
\hline & County & Road & $\mathrm{AC}$ & Granular & PCC & & & \\
\hline 1 & Franklin & $\mathrm{C} 23$ & 191 & 76 & 234 & Yes & 120 & 1998 \\
\hline 2 & Mils & L55 & 180 & 0 & 155 & Yes & 820 & 1999 \\
\hline 3 & Black Hawk & D16 & 168 & 0 & 191 & Yes & 1,280 & 2001 \\
\hline 4 & Dubuque & Twelve Mile Road & 132 & 130 & 249 & No & 810 & 2001 \\
\hline 5 & Scott & F33 & 157 & 0 & 150 & No & 445 & 2004 \\
\hline 6 & Winneshiek & IA 139 & 153 & 0 & 174 & No & 1,010 & 2001 \\
\hline
\end{tabular}

non-rubblized PCC layer. Six representative pavement sections listed in Table 1 were primary selected considering state wide location and pavement age in Iowa, US. The selected AC overlay pavement sections included three pavements with rubblized PCC layer and three pavements with non-rubblized PCC layer. The selected three pavement sections with rubblized PCC layer had the similar ranges of pavement layer thickness, traffic volume, and construction year to the selected pavement sections with non-rubblized PCC layer. The experimental test methods included the Falling Weight Deflectometer (FWD), the Dynamic Cone Penetrometer (DCP) and visual distress surveys. Core samples were also conducted to collect insitu material, identify the layer underneath AC layer, and provided space for conducting the DCP test. Since the length of each selected in-situ pavement was not longer (less than $1 \mathrm{~km}$ ), FWD and DCP tests and coring were performed on three locations in each test section - start (A), middle (B), and end (C) point. The visual distress survey was conducted on the entire test section.

\subsection{Nondestructive Test}

FWD has become the standard equipment for evaluating the structural condition of a pavement structure due to the accuracy with which it can measure the deflected shape of a loaded pavement at appropriate rates of loading. The FWD test is conducted by applying dynamic (impulse) loads to the pavement surface, similar in magnitude and duration to that of a single heavy moving wheel load. The response of the pavement system is measured in terms of vertical deformation or deflection over a given area using geophones. In this research, the FWD was used as the main NDT equipment to evaluate the structural condition of the AC overlay pavement sections. Deflection data were collected using Iowa DOT's JILS-20 FWD by applying a step loading sequence of $27,40,53$, and $67 \mathrm{kN}$ $(6,000,9,000,12,000$ and 15,000 lbs) at three different locations (start, middle, and end point) in each test project. The locations of eight geophones in the Iowa DOT's FWD equipment are at $0\left(\mathrm{D}_{0 \mathrm{~mm}}\right), 203\left(\mathrm{D}_{203 \mathrm{~mm}}\right)$, $305\left(\mathrm{D}_{305 \mathrm{~mm}}\right), 457\left(\mathrm{D}_{457 \mathrm{~mm}}\right), 610\left(\mathrm{D}_{610 \mathrm{~mm}}\right), 914\left(\mathrm{D}_{914 \mathrm{~mm}}\right)$, $1219\left(\mathrm{D}_{1219 \mathrm{~mm}}\right)$, and $1524 \mathrm{~mm}\left(\mathrm{D}_{1524 \mathrm{~mm}}\right)$ from the center of FWD plate load.

\subsection{Destructive Test}

A DCP test as a main destructive test was conducted at the same locations after coring where a FWD test were conducted. The DCP tests were conducted to collect additional information about the in-situ subgrade soil properties. The DCP is an in situ device where measurements of penetration per blow (mm/blow) are obtained. In 2009, the ASTM published a standard for use of the DCP (ASTM 2009), "Standard Test Method for Use of the Dynamic Cone Penetrometer in Shallow Pavement Applications". The device works by using a standard $8 \mathrm{~kg}$ (17.6 pound) hammer, which is lifted to the handle and dropped to the anvil, forcing the rod to penetrate the compacted soil area.

\subsection{Distress Survey}

Distress surveys over the entire test section were conducted for the selected project sites identified in the field evaluation program. The distress survey methodology employed was similar to that described in the Strategic Highway Research Program's (SHRP) “Distress Identification Manual for the Long-Term Pavement Performance (LTPP) Project (Miller and Bellinger 2003)". A distinction was made between reflective cracking and low temperature (transverse) cracking. Cracking was identified as "reflective cracking" when the transverse cracks were uniformly spaced (corresponding to PCC joint spacing underneath the AC layer).

\section{Structural Condition of Pavements}

\subsection{FWD test and DCP test results}

Two-frequency FWD tests denoted as D/1 and D/2 in Fig. 2 were conducted on a single location to identify the FWD sensor measurement errors. No significant differences were observed, which confirmed that the employed FWD equipment can produce consistent results for same test material. The measured deflections on geophones were responding linearly to increasing FWD loads (see Fig. 2). This indicated that the deflections at different FWD load levels could be normalized to the deflections at one FWD load level. The measured deflections at 27, 53 and $67 \mathrm{kN}$ of FWD loads were normalized to the deflections at $40 \mathrm{kN}$ of FWD load in accordance with the following equation.

$$
D_{\text {normalized }}=D_{\text {actual }} \times \frac{P_{\text {actual }}}{P_{40 k N}},
$$


in which, $D_{\text {normalized }}=40 \mathrm{kN}$ of FWD load normalized deflection measurement, $D_{\text {actual }}=$ actual deflection measurement, $P_{\text {actual }}=$ actual applied FWD load, $P_{40 k N}=40 \mathrm{kN}$ of FWD load. The rubblized PCC and the non rubblized PCC sections were tested on same or successive days, and $1{ }^{\circ} \mathrm{C}$ difference was measured in-situ. Variability of FWD measures due to temperature is negligible.

Fig. 3 presents the values of normalized deflection at $\mathrm{D}_{0 \mathrm{~mm}}$ of FWD geophone for each test section. The $\mathrm{D}_{0 \mathrm{~mm}}$ deflection provides an indication of the overall pavement strength. As seen in Fig. 3 , the average $D_{0 m m}$ value of $262 \mu \mathrm{m}$ in rubblized PCC sections is slightly lower than that of $281 \mu \mathrm{m}$ in non rubblized PCC sections. This result indicates that AC overlay with rubblized PCC pavement has better or at least similar overall pavement strength to AC overlay with non-rubblized PCC pavement.

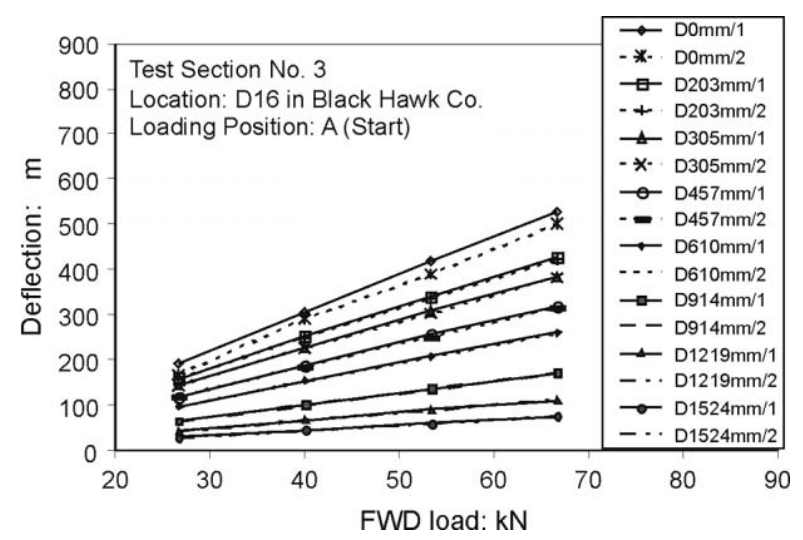

Fig. 2. FWD deflections with loads

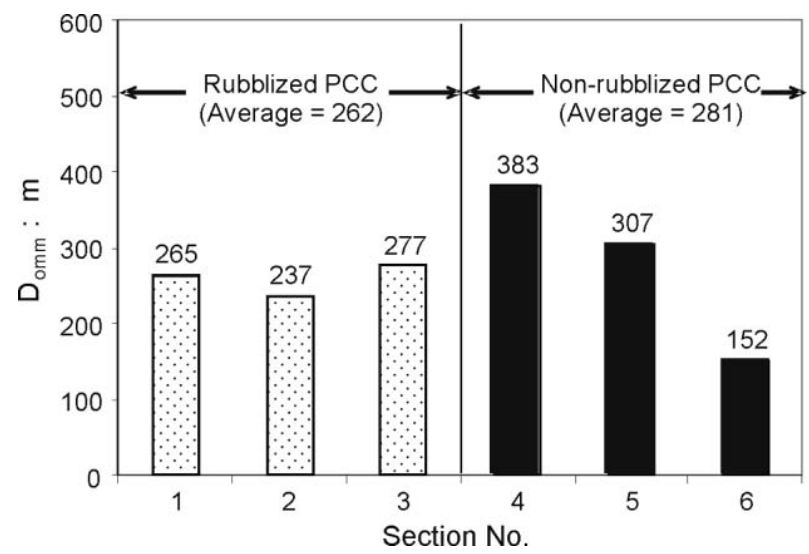

Fig. 3. FWD deflection at $\mathrm{D}_{0 \mathrm{~mm}}$ in test sections

The DCP measures as shown in Fig. 4a has been correlated to the California Bearing Ratio (CBR, percent) which has been further correlated to the resilient modulus $\left(M_{r}\right)$. The values of $M_{r}$ for each test section were calculated using the DCP measure - CBR-M $\mathrm{M}_{\mathrm{r}}$ Correlation equations (ASTM 2009; NCHRP 2004) shown below.

$$
\begin{gathered}
C B R(\%)=\frac{292}{D C P I^{1.12}}, \\
M_{r}(p s i)=2555(C B R)^{0.64} .
\end{gathered}
$$

CBR is the California Bearing Ratio (\%), DCPI is the dynamic cone penetration index ( $\mathrm{mm} / \mathrm{blow})$, and $\mathrm{M}_{\mathrm{r}}$ is the resilient modulus (psi). As seen in Fig. $4 b$, the average $M_{r}$ value of $80 \mathrm{MPa}$ in rubblized PCC sections is higher than that of $71 \mathrm{MPa}$ in non rubblized PCC sections. However, the higher average of $M_{r}$ values in rubblized PCC sections may not be significant considering higher variation within test sections. This result indicates that the rubblization could be performed on subgrade conditions similar to that of AC overlaid non-rubblized PCC pavements.

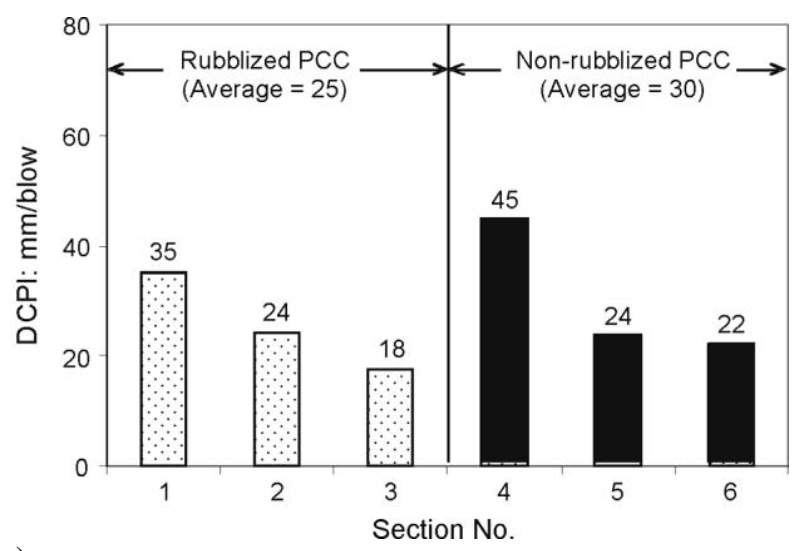

a)

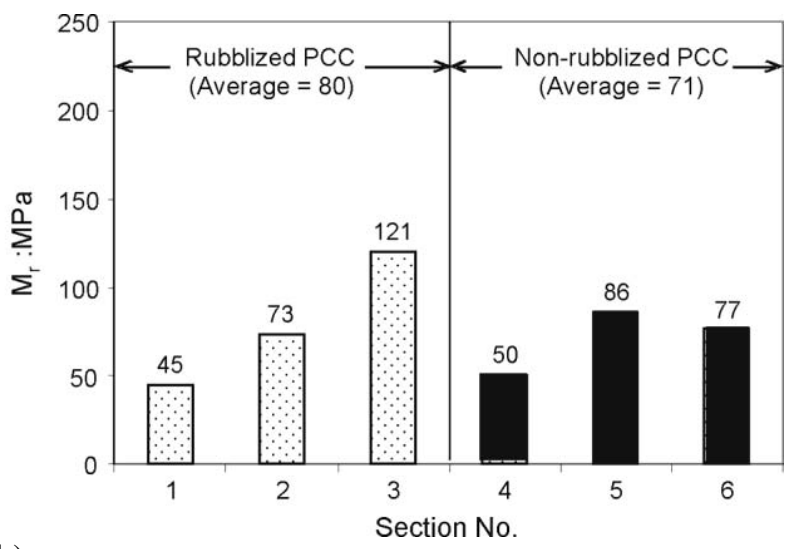

b)

Fig. 4. DCPI and $M_{r}$ in test sections: a) DCPI; b) $M_{r}$

\subsection{Deflection Basin Parameters (DBPs)}

Using the measured FWD surface deflections, Deflection Basin Parameters (DBPs) were derived to characterize the structural condition of in-service pavements. Based on a comprehensive literature review, the most widely used and effective DBPs were identified. These parameters are AREA shape parameter, Area Under Pavement Profile (AUPP), Impact Stiffness Modulus (ISM), Surface Curvature Index (SCI), Base Curvature Index (BCI), and 
Base Damage Index (BDI). The definitions of these DBPs and their significance are discussed in here.

The AREA shape parameter defines the stiffness of the pavement structure as a shape factor. It is the area under the deflection basin curve (normalized with respect to $\left.\mathrm{D}_{0 \mathrm{~mm}}\right)$ using Simpson's rule. Thus, the AREA is a function of sensor location and has units of length ( $\mathrm{mm}$ or inches). The maximum value cannot be greater than $914 \mathrm{~mm}$ (36 inches) corresponding to the case when the four sensor measurements are equal. The minimum AREA can be assumed to be the value computed using the elastic half-space model (the Boussinesq model). For most pavements, the FWD AREA will range from 281.9 to $914.4 \mathrm{~mm}$ (11.1 to 36 inches). The AREA parameter was initially proposed by Hoffman and Thompson (1982). The AREA is defined as:

$$
\operatorname{AREA}(\mathrm{mm})=\frac{6\left(D_{0 \mathrm{~mm}}+2 D_{305 \mathrm{~mm}}+2 D_{610 \mathrm{~mm}}+D_{914 \mathrm{~mm}}\right)}{D_{0 \mathrm{~mm}}} .
$$

The Area Under Pavement Profile (AUPP) proposed by Hill and Thompson (1988) is also a FWD deflection basin shape parameter which is dimensionless. Its definition is complimentary to the AREA parameter, i.e., lower AUPP corresponds to higher pavement stiffness. Based on extensive ILLI-PAVE database (Hill and Thompson 1988), the horizontal strain at the bottom of the AC layer $\left(\varepsilon_{\mathrm{AC}}\right)$ has been correlated with the AUPP term for conventional and full-depth flexible pavements. Garg and Thompson (1998) and Alvarez and Thompson (1998) validated the $\varepsilon_{\mathrm{AC}}-\mathrm{AUPP}$ relations based on the analyses of Mn/ROAD field data (FWD testing and AC strain gauge readings). They were found to be valid at various load levels. The AUPP is defined as:

$$
A U P P=\frac{5 D_{0 \mathrm{~mm}}-2 D_{305 \mathrm{~mm}}-2 D_{610 \mathrm{~mm}}-D_{914 \mathrm{~mm}}}{2} .
$$

The Impact Stiffness Modulus (ISM) is defined as the load required for producing unit deflection. It is computed as the ratio of FWD plate load (P) over maximum surface deflection $\left(\mathrm{D}_{0 \mathrm{~mm}}\right)$ and is frequently used in airport pavement evaluation. The ISM is defined as (FAA 2004):

$$
I S M(\mathrm{MPa} / \mathrm{mm})=\frac{P}{D_{0 \mathrm{~mm}}} .
$$

Surface Curvature Index (SCI) can provide information on changes in relative strength of the near-surface layers, especially the AC layer. Based on their Finite Element (FE) analyses, Xu et al. (2001) found that for a certain thickness of the AC layer, the AC moduli and SCI values exhibit an approximately linear relationship in a $\log$-log scale. The SCI has the same meaning as AUPP, i.e., lower SCI values mean higher pavement stiffnesses. The SCI is defined as:

$$
S C I(\mu \mathrm{m})=D_{O \mathrm{~mm}}-D_{305 \mathrm{~mm}} .
$$

The Base Curvature Index (BCI) is a subgrade condition indicator especially in aggregate base pavements and is strongly related to the subgrade modulus (Kilareski and Anani 1982; Horak 1987; Xu et al. 2001). The BCI is defined as:

$$
B C I(\mu \mathrm{m})=D_{610 \mathrm{~mm}}-D_{914 \mathrm{~mm}} .
$$

The Base Damage Index (BDI) is related to base layer modulus. The BDI is defined as:

$$
B D I(\mu \mathrm{m})=D_{305 \mathrm{~mm}}-D_{610 \mathrm{~mm}} .
$$

\section{Comparison of DBPs in AC overlaid pavements with rubblized PCC layer and virgin PCC layer}

The AREA, AUPP and ISM values for test sections are displayed in Fig. 5. Similar information for SCI, BCI and

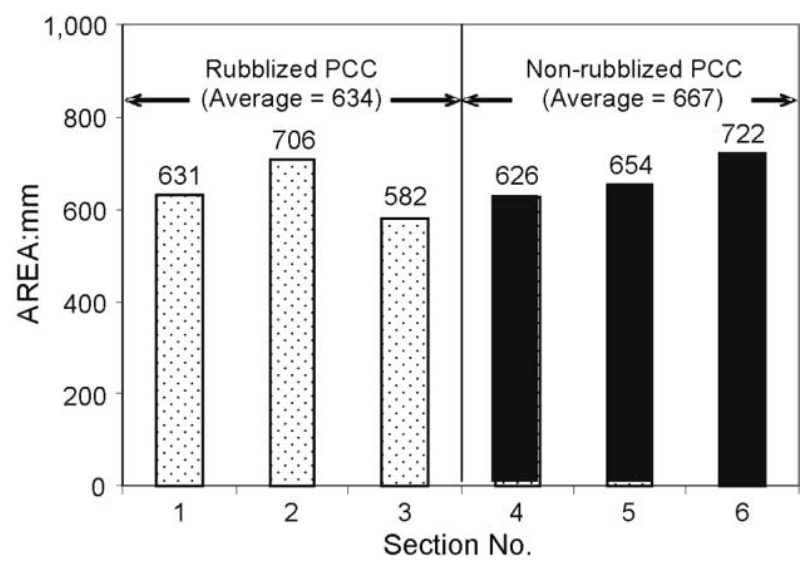

a)

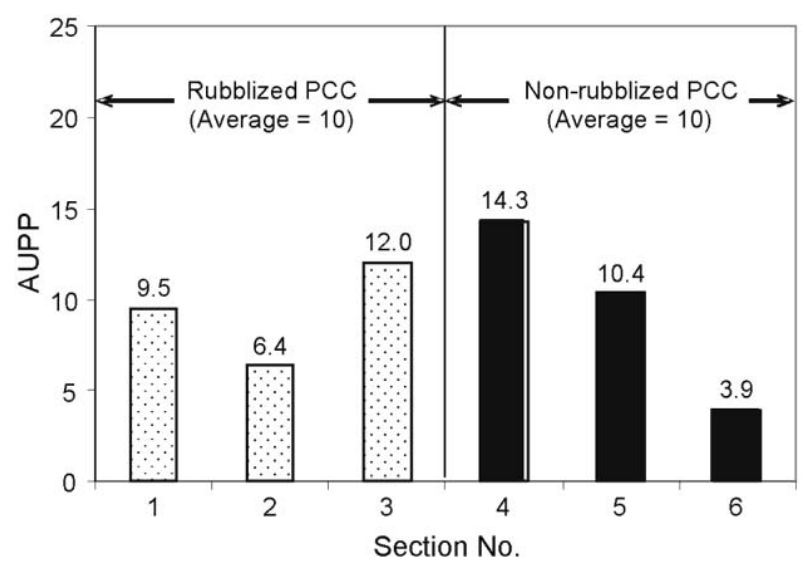

b)

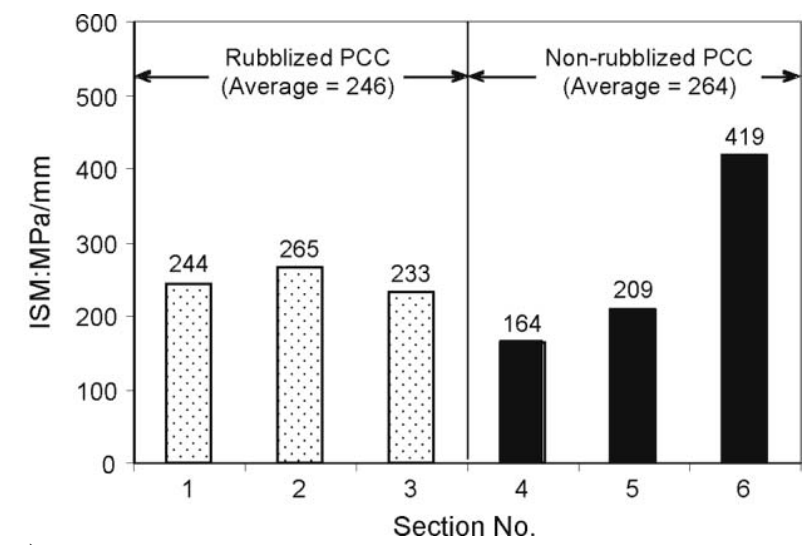

c) 
Fig. 5. AREA, AUPP and ISM in test sections: a) AREA; b) AUPP; c) ISM

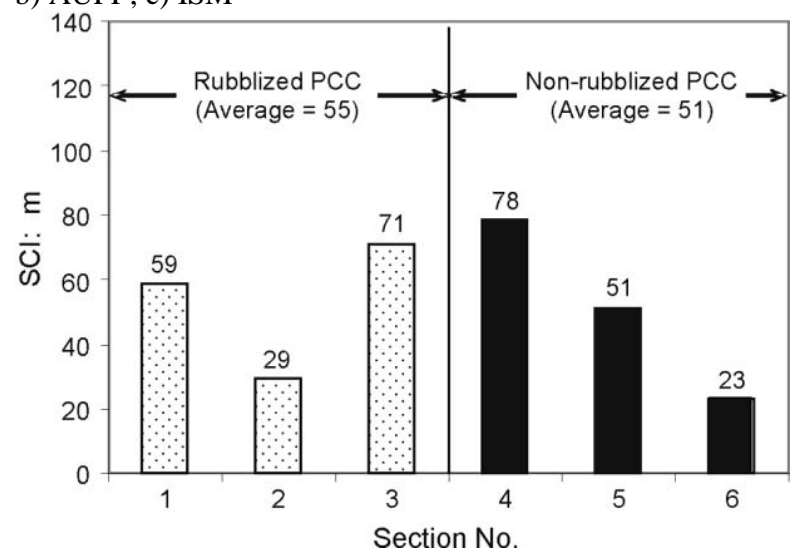

a)

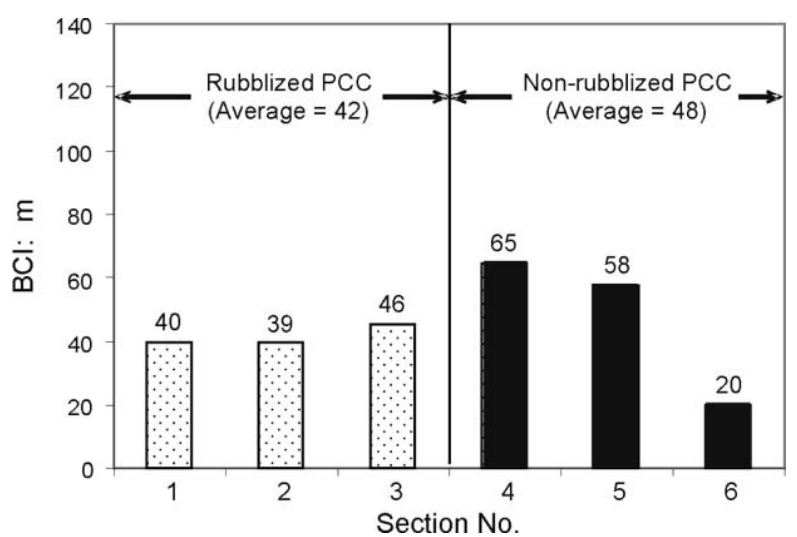

b)

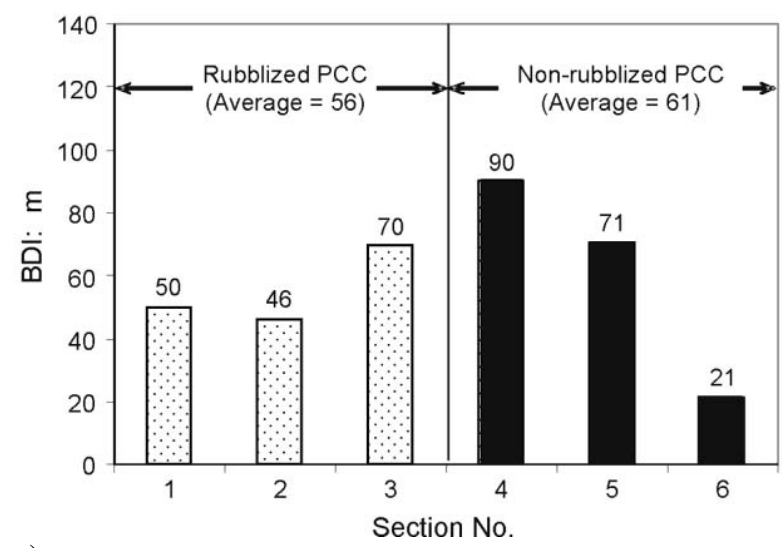

c)

Table 2. Summary of visual distress survey results

\begin{tabular}{cllccl}
\hline $\begin{array}{c}\text { Test Section } \\
\text { No. }\end{array}$ & County & \multicolumn{1}{c}{ Location } & $\begin{array}{c}\text { Rubbli- } \\
\text { zation? }\end{array}$ & $\begin{array}{c}\text { Pavement Ages } \\
\text { at survey }\end{array}$ & Visual Distress Survey Results \\
\hline 1 & Franklin & C23 & Yes & 9 & No cracks \\
2 & Mils & L55 & Yes & 8 & 14 low temperature cracks \\
3 & Black Hawk & D16 & Yes & 6 & 11 low temperature cracks \\
4 & Dubuque & Twelve Mile Road & No & 6 & 6 low temperature cracks \\
5 & Scott & F33 & No & 3 & 24 low temperature cracks \\
6 & Winneshiek & IA 139 & No & 6 & More than 10,000 reflection \\
& & & & & cracks \\
\hline
\end{tabular}
c) BDI

BCI are displayed in Fig. 6. Overall pavement structure strength condition can be related to AREA, AUPP and ISM. SCI can provide information on changes in relative strength of the near-surface layers. BCI is a subgrade condition indicator especially in aggregate base pavements and is strongly related to the subgrade modulus. BDI is related to base layer modulus. Higher values of AREA and ISM mean higher pavement stiffnesses. On the other hand, lower values of AUPP, SCI, BCI, and BDI mean higher pavement stiffnesses.

It is observed from these figures that although there is some variation in each test section, the average values of DBPs are not significantly different between the rubblized PCC sections and the non-rubblized PCC sections. As seen in Fig. 5, both sections have similar overall pavement condition indicated from average values of AREA, AUPP and ISM. Especially, the average BDI value of $56 \mu \mathrm{m}$ in rubblized PCC sections is slightly lower to that of $61 \mu \mathrm{m}$ in non rubblized PCC sections as shown in Fig. 6c. Considering that BDI is related to the strength of base layer (rubblized PCC or non-rubblized PCC layer) and lower values of BDI mean higher stiffness, this result indicates that the strength of rubblized PCC layer are comparable, or even better, to that of PCC layer without rubblization.

\section{Surface Condition of Pavements}

Distress survey results are summarized in Table 2. In general, no load-associated distresses, such as fatigue cracking, were found in any of the test sections as shown in Fig. 7. The predominant distresses observed in the rubblized PCC sections are low-temperature cracks as shown in Fig. 8. No reflection cracking was observed in these rubblized PCC sections. However, some of the nonrubblized PCC section, especially IA-139 in Winneshiek County (No. 6), showed high-severity reflection cracking, as shown in Fig. 9. These results indicate that the rubblized pavement sections in Iowa have better performance under structural conditions comparable to that of non-rubblized sections.
Fig. 6. SCI, BCI and BDI in test sections: a) SCI; b) BCI; 


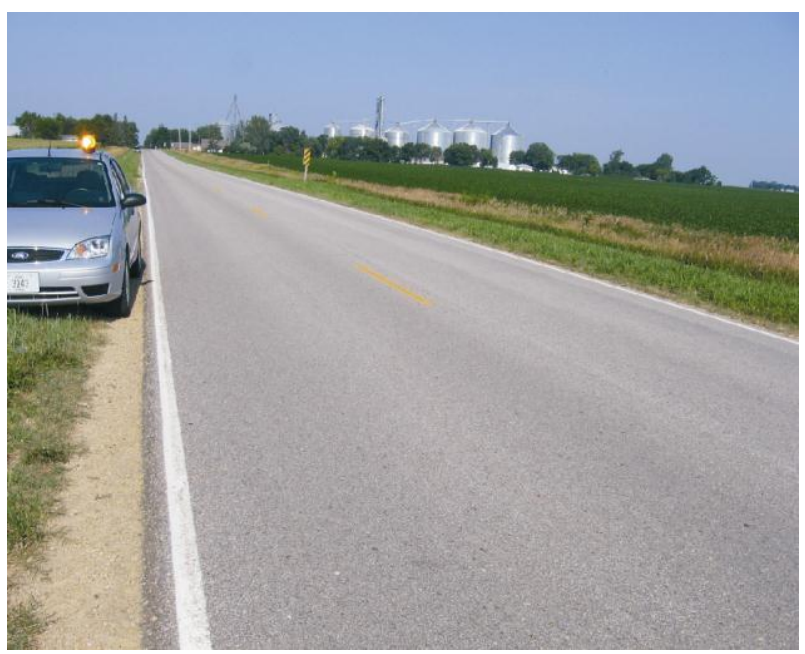

Fig. 7. Picture of distress-free AC surface on rubblized PCC layer (No. 1: C23 in Franklin County)

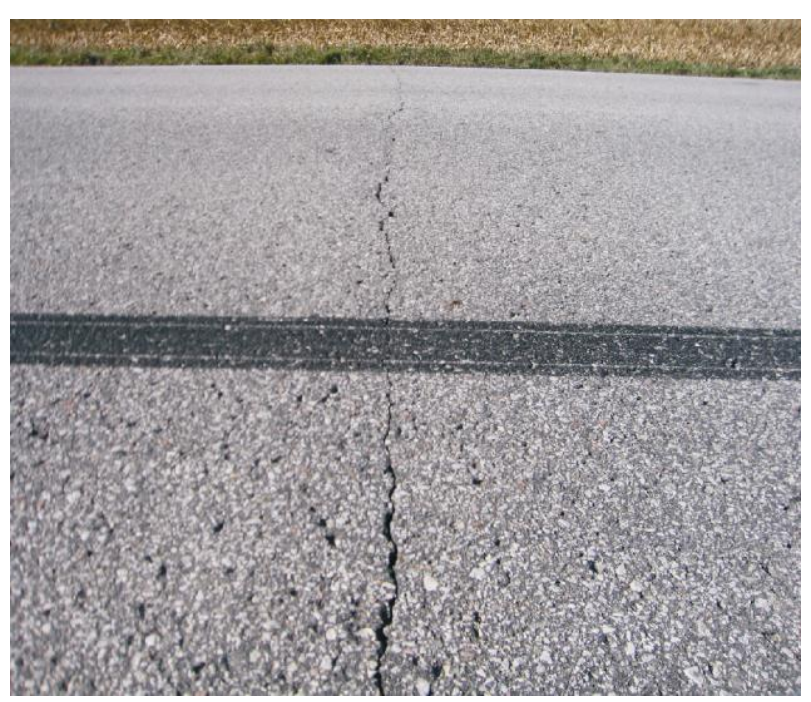

Fig. 8. Picture of low-temperature cracking on AC-overlaid rubblized PCC pavement (No. 3: D16 in Black Hawk County)

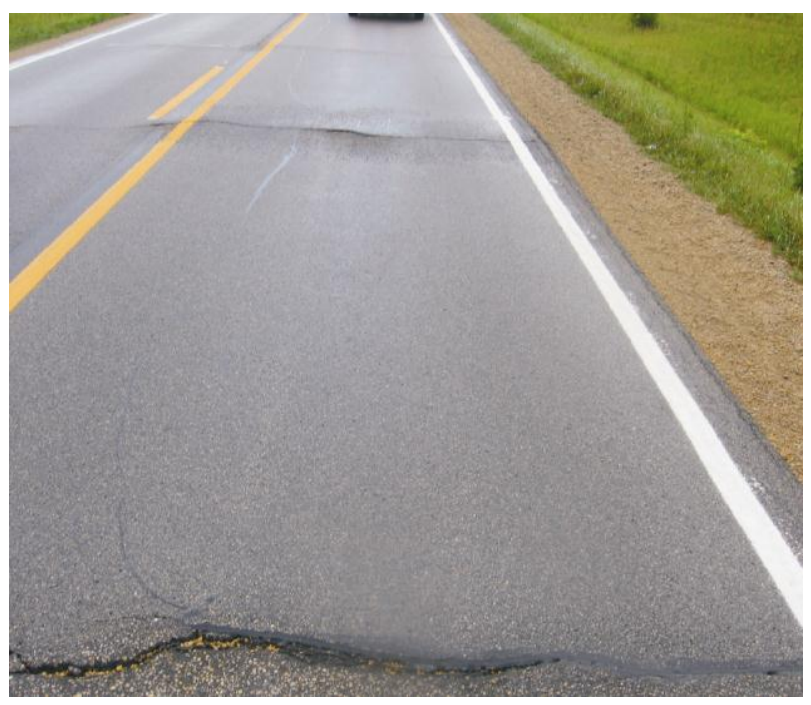

Fig. 9. Picture of reflection cracking on AC-overlaid virgin PCC pavement (No. 6: IA139 in Winneshiek County)

\section{Conclusions}

The current practices on the use of rubblization are briefly presented. The structure condition information of six representative $\mathrm{AC}$ overlay pavement with and without rubblization were collected with Nondestructive and destructive test methods. The Deflection Basin Parameters (DBPs) derived from Nondestructive test (NDT) were used to evaluate the structural condition of rubblized PCC sections in comparison to that of non-rubblized PCC sections. The surface conditions of AC overlay pavement with rubblization and without rubblization were compared through distress survey. It was found that the rubblized PCC layer had comparable strength to PCC layer without rubblization and it has contributed to prevention of reflection cracking. These results indicate that rubblized pavements in Iowa have better performance under the structural conditions comparable to that of nonrubblized pavement sections.

\section{Acknowledgments}

The authors gratefully acknowledge the Iowa Highway Research Boards (IHRB) and the Iowa Department of Transportation (DOT) for supporting this study. The contents of this paper reflect the views of the authors who are responsible for the facts and accuracy of the data presented within. The contents do not necessarily reflect the official views and policies of the Department of Transportation. This paper does not constitute a standard, specification, or regulation.

\section{References}

Alabama DOT. 2006. 2006 Standard Specification [online], [accessed 10 September 2007]. Available from Internet: <http://www.dot.state.al.us/NR/rdonlyres/A7030997-448E4070-AD43-29836F663A97/0/2006_Spec_Book.pdf.>.

Alvarez, C.; Thompson, M. R. 1998. Mechanistic Empirical Evaluation of the Mn/Road Mainline Flexible Pavement Sections, Transportation Engineering Series No. 97, Department of Civil Engineering, University of Illinois at Urbana-Champaign, Urbana, Illinois.

Antigo Construction, Inc. 2007 [online], [accessed 10 September 2007]. Available from Internet: $<$ http://www.antigoconstruction.com/>.

Arkansas DOT. 2003. 2003 Standard Specifications for Highway Construction [online], [accessed 10 September 2007]. Available from Internet: $<$ http://www.arkansashighways com/Contract/progcon/general/STDSPECS_2003.HTM>.

ASTM. 2009. D6951: Standard Test Method for Use of the Dynamic Cone Penetrometer in Shallow Pavement Applications. American Society for Testing and Materials, West Censhohocken, Philadelphia.

Baladi, G.; Svasdisant, T.; Chatti, K. 2002. Report No. MDOTPRCE-MSU-1999-110: Identify Causes for Under Performing Rubblized Concrete Pavement. East Lansing, Michigan.

Chen, D. H.; Huang, Q.; Ling, J. 2008. Shanghai's experience on utilizing the rubblization for jointed concrete pavement rehabilitation, Journal of Performance of Constructed Facilities 22(6): 398-407. doi:10.1061/(ASCE)0887-3828(2008)22:6(398) 
Ellis, S. J.; Langdale, P. C.; Cook, J. 2002. Performance of techniques to minimize reflection cracking and associated developments in pavement investigation for maintenance of uk military airfields, in Proceedings of the 2002 Federal Aviation Administration Airport Technology Transfer Conference, Chicago, Illinois.

FAA. 2004. Use of Nondestructive Testing in the Evaluation of Airport Pavements. FAA Advisory Circular No. 150/ 5730-11A, Office of Airport Safety and Standards, Federal Aviation Administration, U.S. Department of Transportation, Washington, DC.

Fitts, G. L. 2001. Performance observations of rubblized PCC pavements, in Proceedings of Second International Symposium on Maintenance and Rehabilitation of Pavements and Technological Control, Auburn, Alabama.

Freeman, T. E. 2002. Report No. VTRC 03-R3: Evaluation of Concrete Slab Fracturing Techniques in Migrating Reflective Cracking through Asphalt Overlays. Virginia Transportation Research Council, Charlottesville, Virginia.

Garg, N.; Thompson, M. R. 1998. Mechanistic Empirical Evaluation of The Mn/Road Low Volume Road Test Sections, Transportation Engineering Series No. 96, Department of Civil Engineering, University of Illinois at Urbana-Champaign, Urbana, Illinois.

Gucunski, N.; Sauber, R.; Maher, A.; Rascoe, C. 2009. Modulus of rubblized portland cement concrete from surface wave testing, Transportation Research Record 2104: 34-41. doi:10.3141/2104-04

Gulen, S.; Noureldin, A. S.; Weaver, J. 2004. Report No. FHWA/IN/JTRP - 2004/8: Life and Cost Comparison of Three Rehabilitation Techniques on I-65 between SR-2 and $S R-114$. Indiana Department of Transportation, West Lafayette, Indiana.

Heckel, L. B. 2002. Report No. IL-PRR-137: Rubblizing with Bituminous Concrete Overlays - 10 years Experience in Illinois. Illinois Department of Transportation, Springfield, Illinois.

Hill, H. J.; Thompson, M. R. 1998. Early Life Study of the FA409 Full-Depth Asphalt Concrete Pavement Sections, University of Illinois Research Report, University of Illinois at Urbana-Champaign, Urbana, Illinois.

Hoffman, M. S.; Thompson, M. R. 1982. Backcalculating nonlinear resilient moduli from deflection data, Transportation Research Record 852: 42-51.

Horak, E. 1987. The use of surface deflection basin measurements in the mechanistic analysis of flexible pavements, in Proceedings of the Sixth International Conference on Structural Design of Asphalt Pavements University of Michigan, Ann Arbor-July 13-17, 1987 I: 5-10.

Indiana DOT. 2006. 2006 Standard Specifications [online], [accessed 10 September 2007]. Available from Internet: <http://www.in.gov/dot/div/contracts/standards/book/sep0 6/sep.htm>.

Kilareski, W. P.; Anani, B. A. 1982. Evaluation of in-situ moduli and pavement life from deflection basins, in Proceedings of the Fifth International Conference on Structural Design of Asphalt Pavements, 1: 349-366.

Ksaibati, K.; Miley, W. J.; Armaghani, J. 1998. Report No. FL/DOT/SMO/98-426: Rubblization of Concrete Pavements. Florida Department of Transportation, Gainesville, Florida.

Michigan DOT. 2003. 2003 Standard Specifications [online], [accessed 10 September 2007]. Available from Internet: <http://mdotwas1.mdot.state.mi.us/public/specbook/>.
Miller, J. S.; Bellinger, W. Y. 2003. Report No. FHWA-RD-03031 (4th edition): Distress Identification Manual for the Long-Term Pavement Performance (LTPP) Project. Federal Highway Administration. Mclean, Virginia.

National Asphalt Pavement Association (NAPA). 1994. Guidelines for use of HMA overlays to rehabilitate PCC pavements. Information Series 117, Maryland.

National Cooperative Highway Research Program (NCHRP). 2004. Guide for Mechanistic-Empirical Design of New and Rehabilitated Pavement Structures [online], [accessed 10 May 2006]. Available from Internet: <http://trb.org/mepdg>, National Cooperative Highway Research Program 1-37A, Transportation Research Board, National Research Council, Washington, DC.

Ohio DOT. 2005. 2005 Construction and Material Specifications [online], [accessed 10 Sep. 2007]. Available from Internet: <http://www.dot.state.oh.us/construction/OCA/ Specs/2005CMS/2005_ODOT_C\&MS.htm>.

PCS/Law. 1991. Guidelines and Methodologies for the Rehabilitation of Rigid Highway Pavements Using Asphalt Concrete Overlays. Maryland.

Resonant Machines, Inc. 2007 [online], [accessed 10 September 2007]. Available from Internet: <http://www.resonantmachines.com>.

Rolt, J.; Smith H. R.; Jones, C. R. 1986. The design and performance of bituminous overlays in tropical environments, in Proceedings of the 2nd International Conference on Bearing Capacity of Roads and Airfields, Plymouth, UK.

Rolt, J.; Hasim, M. S.; Suffian, Z. 1996. The prediction and treatment of reflection cracking in thin bituminous overlays, in Proceedings of the Second Malaysian Road Conference 96, Kuala Lumpur, Malaysia.

Scullion, T. 2006. Nondestructive testing results from the rubblized concrete pavement on interstate 10 in Louisiana, in Transportation Research Circular E-C087: Rubblization of Portland Cement Concrete Pavements, Transportation Research Board, National Research Council, Washington, DC.

Thompson, M. R.; Van Matre, F. R.; Lippert, D.; Jenkins, P. 1997. HMA overlay construction with one-pass/lanewidth PCCP rubblization, Journal of the Association of Asphalt Paving Technologists 66: 407-417.

Timm, D. H.; Warren, A. M. 2004. Report No. IR-04-02: Performance of Rubblized Pavement Sections in Alabama. Highway Research Center, Auburn University, Auburn, Alabama.

Von Quintus, H. L.; Rao, C.; Mallela, J.; Aho, B. 2007. Report No. WHRP 06-13: Guidance, Parameters, and Recommendations for Rubblized Pavements. Wisconsin Department of Transportation, Madison, Wisconsin.

Wienrank, C. J.; Lippert, D. L. 2006. Illinois performance study of pavement rubblization, in Transportation Research Circular E-C087: Rubblization of Portland Cement Concrete Pavements, Transportation Research Board, National Research Council, Washington, DC.

Wisconsin DOT. 2007. Facilities Development Manual [online], [accessed 10 September 2007]. Available from Internet: <https://trust.dot.state.wi.us/static/standards/fdm/14/ TC14.pdf >.

Xu, B.; Ranjithan, S. R.; Kim, Y. R. 2001. Development of relationships between FWD deflections and asphalt pavement layer condition indicators, in Proceedings of the 81st Annual Meeting of the Transportation Research Board (CD-ROM), Washington, DC. 


\section{REKONSTRUOTŲ BETONINIŲ KELIO DANGŲ VERTINIMAS NEARDOMAISIAIS METODAIS}

\section{K. Gopalakrishnan, S. Kim, H. Ceylan}

\section{Santrauka}

Siekiant nustatyti asfaltbetonio (AC) sluoksnio veiksmingumą, mažinant plyšių ir įtrūkių atsiradimą portlandcemenčio betono (NKK) dangose, buvo taikyti keli kelio dangų rekonstrukcijos metodai. Vertinant ịvairius plyšių susidarymą mažinančius kelių rekonstrukcijos metodus, geriausiu buvo pripažintas regeneracijos metodas (PCC rubblization), taikomas JAV.

Nagrinejjama minèto regeneracijos metodo taikymo patirtis JAV ir analizuojamos jo taikymo galimybès bei veiksmingumas. Šị kelių atnaujinimo metodą taiko JAV Transporto departamentas (DOT). Siekiant ịvertinti nagrinejjamo regeneracijos metodo veiksmingumą eksploatacinėmis sąlygomis, AC buvo padengtas pagal naujajj metodą paruoštu PCC sluoksniu, ir gauti tyrimų rezultatai palyginti su standartiškai paruošto PCC sluoksnio rezultatais. Natūriniai eksperimentiniai bandymai buvo atlikti, taikant neardomuosius (NDT) ir ardomuosius tyrimų metodus. Illinkiai (DBPs) buvo nustatyti NDT bandymo metodais, charakterizuojančiais konstrukcines dangų sąlygas.

Darbo rezultatai parodè, kad pagal naujaji metodą paruoštas PPC sluoksnis igijo panašų stiprị kaip ir PCC sluoksnis su standartine danga, tačiau regeneruota PPC danga ịgijo geresnių eksploatacinių charakteristikų.

Reikšminiai žodžiai: betonas, asfaltas, rekonstrukcija, danga, neardomieji metodai, regeneracija.

Kasthurirangan GOPALAKRISHNAN. Dr, research Assistant Professor in the Department of Civil Construction, and Environmental Engineering at Iowa State University, Member of the American Society of Civil Engineers (ASCE) as well as the lead Editor of Springer's Intelligent and Soft Computing in Infrastructure Systems Engineering and Sustainable and Resilient Critical Infrastructure Systems. He received the Dwight D. Eisenhower Transportation Fellowship Award in 1999 and he completed his PhD in 2004 at the University of Illinois at Urbana-Champaign, USA.

His research interests include the use of bio-inspired computing paradigms in civil engineering informatics, sustainable and green technologies, simulation, imaging, and mechanics of transportation infrastructure systems.

Sunghwan KIM. Dr, Postdoctoral Research Associate in the Department of Civil Construction, and Environmental Engineering at Iowa State University, Member of the American Society of Civil Engineers (ASCE) as well as the Association of Asphalt Paving Technologists (AAPT). Received his Ph.D. in 2006 at Iowa State University, USA. His research interests include the renewable transportation infrastructure materials and recycling construction technique, the mechanisticbased pavement analysis and design, and the nondestructive testing and evaluation (NDE) of transportation infrastructure systems. He is a registered professional engineer (P.E.) in the state of Michigan, USA.

Halil CEYLAN. Dr, an Associate Professor in the Department of Civil Construction, and Environmental Engineering at Iowa State University, Member of the American Society of Civil Engineers (ASCE) as well as an Editorial Board Member of the "Baltic Journal of Road and Bridge Engineering". Received his Ph.D. in 2002 at the University of Illinois at Urbana-Champaign, USA. His research interests include the nondestructive testing and evaluation, mechanistic-based pavement analysis, design and performance prediction, and infrastructure/engineering materials. 